\title{
Food security in South Africa: are the correlates the same for rural and urban households?
}

\author{
1,*'Oluwatayo, I.B., ${ }^{2}$ Marutha, M.I. and ${ }^{2}$ Modika, M.P. \\ ${ }^{1}$ Department of Agricultural Economics and Agribusiness, University of Venda, Thohoyandou, 0950, South \\ Africa \\ ${ }^{2}$ Department of Agricultural Economics and Animal Production, University of Limpopo, Sovenga 0727, \\ South Africa
}

\author{
Article history: \\ Received: 24 June 2020 \\ Received in revised form: 9 \\ July 2020 \\ Accepted: 29 July 2020 \\ Available Online: 1 \\ November 2020
}

Keywords:

Correlates,

Determinants,

Food security,

Rural and urban areas,

South Africa

DOI:

https://doi.org/10.26656/fr.2017.5(1).298

\begin{abstract}
Food security is a serious issue topping the developmental agenda of most countries across the globe. This is one of the key issues highlighted in the sustainable development goals (SDGs) of which most countries are signatories to. South Africa, a developing country in Africa is not spared of the pang of food insecurity considering the number of inhabitants of the country that are food insecure especially in the rural communities of the country. This review paper, therefore, explores and correlates food security in South Africa to ascertain whether the drivers in the rural and urban areas are the same. Delineation of these correlates is considered to be pertinent for right targeting of the poor and highly vulnerable households and individual since national food security is not tantamount to food security at household and individual levels. The paper concludes that income and educational status of households are key determinants of food security and hence, the need to intensify efforts at enhancing the capacity of households in South Africa through education to translate for better jobs and increase income-earning opportunities.
\end{abstract}

\section{Introduction}

Food security has always been a challenge in developing countries especially in sub-Sahara Africa simply because there has never been a one cap fits all definition of this concept. While some researchers defined it from a national level perspective forgetting that food security level at the national level does not automatically translate to food security at household and individual levels, others defined it narrowly focusing on one or two of its dimensions. According to FAO (2004) and Krishnaraj (2005), food security is contingent on three dimensions namely; availability, accessibility and affordability. The accessibility and availability of food are related to the distribution and production processes, however, the affordability is a much more complex concept and can be explained based on the Amartya Sen's (1981) concept of endowment where the resources that one possesses determine the one's capacity to buy. According to Bwalya (2013), sub-Sahara Africa is the most food-insecure continent in the world.

The United Nations' Human Development Report (United Nations, 2012) and FAO, ECA and AUC (2020) reported that one in four households in sub-Saharan
Africa cannot access adequate food and that the worsening food security situation in this region is due to climate shocks, conflict and economic slowdowns and downturns. Therefore, achieving food security is still a major challenge as majority of the countries in subSaharan region find it difficult to achieve the Millennium Development Goals (MDGs) of halving the percentage of those affected by hunger by 2015 (Millennium Development Goals, 2015). This was the situation despite various reported policy implementations and improvements in economic development in the region (Bremner, 2012). The challenge of food security is exacerbated by the rapid rise in the population resulting in the need for increased quantities of food to feed millions of households. The rise in the cost of food is another risk factor to households' food security because many of the sub-Sahara African countries import food as agricultural production and technology is still relatively low due to scarce resources (United Nations, 2012).

According to Pinstrup-Andersen (2009), the definition of food security that was agreed upon at the World Food Summit in 1996 is that food security refers to the condition where all people, at all times, have 
physical and economic access to sufficient, safe and nutritious food to meet their dietary needs and food preferences for a healthy and active life. In the definition developed at the World Food Summit, "safe and nutritious" emphasizes food safety and nutritional composition while "food preferences" changes the concept of food security from just the access to enough food but the availability, affordability and accessibility to the food preferred. This, therefore, gives an indication that there are different levels of food security, where those with different food preferences have varied levels of food security. Though we know that preference can be defined from an individual perspective as the greater liking of a certain alternative over the other. The concept of food security complicates things when we use Pinstrup-Andersen (2009) idea in defining food preference which is interpreted to mean foods that are socially and culturally acceptable and consistent with religious and ethical values, rather than a broader interpretation to mean a household or individual preference.

Labadarios et al. (2011) indicated that in recent years, particular attention has been paid to access to food and its measurement. This stems from the realisation that even when food is available in the markets, it may not be accessible to specific households. A huge amount of money is spent each year with the intentions to reduce hunger yet the definition of food security makes it difficult to conclude if the objective is being met or not on a yearly basis. To meet this objective, those who are in the greatest risk of food insecurity should be prioritised first when food security programmes are to take place.

Emanating from the foregoing, it is very important to understand that the challenge of food insecurity is multifaceted and requires that effort be made to unravel its dynamics in terms of where the household resides. It is in view of this that this review become very pertinent to unravel some of the correlates of food insecurity in rural and urban South Africa as this will ensure priotisation and better targeting of those most affected by the pang of food insecurity.

\section{The state of food security in South Africa}

The issue of food security is dated way back and considered as precarious in various parts of the world. In South Africa, the right of access to sufficient food was embedded in Section 26 and 27 of the South African Constitutional law of 1996. According to the constitution of South Africa (du Toit, 2011), every citizen has a right to safe, nutritious and sufficient food, water and social security. It is after 1994 when South Africa became a democratic country that food security received more attention. In light of section 26, the Department of Agriculture, Forestry and Fisheries was mandated to develop agricultural policies and support programmes to ensure that South African citizens are given opportunities that will enable them to meet their basic food needs.

In the 2010/2011 financial year, food security was re -prioritised as one of the top priorities for the South African government (Ramaila et al., 2011). This is in line with South Africa's Millennium Development Goal (MDG) which aims to halve the proportion of people who go hungry over the period of 1990 and 2015 and to halve poverty and unemployment by 2014. For this objective to be achieved, the starting point should be the achievement of household food security. Therefore, the government adopted the Integrated Food Security Strategy (IFSS) in 2002. The Department of Agriculture, Forestry and Fisheries (DAFF)'s major role is, among others, to make sure that there are enough opportunities to encourage South Africans to participate in the agricultural chain of food production to reduce food insecurity in the country. The department has since initiated a number of programmes that are meant to contribute positively to food security in the country (Ramaila et al., 2011).

According to FAO (2008), South Africa is a food secure nation with the capacity to produce enough staple food and also import enough food, if needed in order to meet the basic nutritional requirements of its population. Food security is primarily dependant on the country's ability to produce enough food for the citizens. If sufficient amounts of food are not produced domestically, countries need to import from other countries. Importation as a result of the local producers' inability to produce enough increases the price of food. The higher the price of food, the more the country's vulnerability to food insecurity. Large commercial farmers in South Africa produce the main staple foods and exports the surplus. Field crops, livestock and horticulture are the main agricultural sectors of South Africa with wine and fruit production growing substantially in the past decade (Van der Merwe, 2011).

South Africa has a dualistic agricultural economy, comprising of a well-developed commercial farming sector co-existing with the small-scale farming sector, which is mainly practised on a subsistence basis. Hart (2009) supported the argument that South Africa seems to be food secure at the national level but the same cannot be said about households in rural areas. Regardless of the political and economic advancements seen in South Africa since 1994, the country is still being 
plagued by poverty, unemployment, rising food and fuel prices, high-energy tariffs and increasing interest rates and according to Statistics South Africa (StatsSA) (2019) and Oluwatayo (2019), food security is still a national crisis in the country. These adverse conditions have placed severe pressure on ordinary South Africans already struggling to satisfy their basic household needs. This, therefore, means that the term 'food insecurity' must be correctly defined in the South African context and the measures for food insecurity must be developed based on this definition.

Despite the many years of democracy in South Africa, a large proportion of the citizens still perceive themselves as lacking enough income to meet all their household needs (Labadarios et al., 2011). "Access" is defined as a household's ability to accumulate enough food for all members. Ramaila et al. (2011) reported that an estimated $20 \%$ of South African households have inadequate or severely inadequate food access. According to Chakona and Shackleton (2019), high unemployment rate, inadequate social welfare systems and a high HIV/AIDS infection rate have all contributed to food insecurity in the country. Landman (2004) and Aliber (2004) indicate that food (in)security is a serious challenge that still persists in South Africa after several years of democracy.

National food security indicators reveal that South Africa has been able to meet the food needs of its growing population over the past 8 years. However, there is a dearth of clear statistics to show that food security condition is the same at the household level, especially in rural areas of South Africa. Demetre et al. (2009) confirm that based on the national definition, South Africa is food secure but suggests that quite about 14 million people in the country are estimated to be vulnerable to food insecurity. It is also reckoned that as many as 1.5 million, or about one-quarter of youngsters under the age of 6 were malnourished.

Meanwhile, one of the South African agricultural policy's main objectives is to be self-sufficient when it comes to production. South Africa has achieved this goal by producing a surplus in most of the agricultural commodities. Even though this objective is being achieved yet many South African households and individuals go to bed on empty stomach. This is because of large inequities, resulting from poor food distribution networks and a high level of malnutrition experienced (van Zyl and Kirsten, 1992; Voster, 2010). There is a very strong and correlated relationship between agricultural productivity and food availability. Agricultural productivity growth can assist in reducing poverty (Mozumar, 2012; Oluwatayo, 2019). It may also help in meeting food demands because it will ensure food availability for rural poor people. It can increase the incomes of farm laborers and many of the inhabitants. This can also improve food supplies which can reduce food prices, which in turn increase the real income and help in reducing poverty in rural areas. These channels may help in improving better access to food by rural people.

Participating in agricultural activities by households can reduce the level of food insecurity. Subsistence farming is one agricultural activity that is identified to be effective in reducing hunger at the household level. The result from StatSA General Household Survey - GHS (2017) show that out of 16,2 million households, about 2.5 million households $(15,6 \%)$ were involved in agricultural activities in South Africa in 2017. Provinces that are dominated by rural areas with higher poverty levels and hunger such as Limpopo (25\%), Eastern Cape $(20 \%)$ and KwaZulu-Natal (20\%) have the highest number of households that owned subsistence farms to supply their own food. This, therefore, means there is high correlation between food security, poverty and agricultural production.

\section{Determinants of food security in South Africa - rural and urban dichotomy}

In 2017, about 6,8 million South Africans experienced hunger, even though the number dropped from 13.5 million in 2002, it still affects 1.7 million households across the country (StatSA, 2019). Whilst South Africa is food secure at the national level, the country is still food insecure at the household level as not all households have access to adequate food (DAFF, 2011). Also, the South African National Health and Nutrition Examination Survey - SANHANES (2013) found that $28 \%$ of households nationally are at risk of hunger and a further $26 \%$ experience hunger. In urban informal areas, the proportion of households at risk of hunger was $36 \%$ and correspondingly $32 \%$ experienced hunger (SANHANES, 2013).

The study by Machethe (2004) and Oluwatayo (2019) indicate that food insecurity is deeply rooted in rural areas. According to the results, the majority of poor people are found in rural areas with roughly $75 \%$ of them are chronically poor. The variation was by province, population group of household head and by household size. Limpopo $(93,6 \%)$ and Gauteng $(84,0 \%)$ had the highest proportion of households that reported adequate food access whilst North West $(64,0 \%)$ and Northern Cape $(66,5 \%)$ provinces had the lowest proportions of households that had adequate food access and therefore can be seen as the least food secure (StatsSA, 2017). 
Food insecurity does not only occur in the rural areas but also in urban areas. Many people migrate to urban areas with the hope of improving their welfare. The problem is more complex in the city especially for people who do not have the skills and education needed to get employment resulting in the fragility of household food security (Widayaningsih et al., 2011).

According to the study by Grobler (2015), household food insecurity in urban areas is influenced by household head's age, education, employment status, income, social grants received and spending patterns of the household. The research conducted in rural areas of Limpopo province found a significant and positive relationship between food security and household income, education status, credit access and infrastructural support. The results from both analyses clearly indicated that some of the determinants do not differ irrespective of urban or rural areas. In this case, the educational status of household head influences household food security in both rural and urban setting. This result is supported by the study done by Ndobo (2013) which also showed that the educational status of the household head is a significant factor in determining household food security status.

Food insecurity has traditionally been conceptualised as a rural development problem, the existing conceptual tools used to understand the challenge and frame the responses are inadequate to address food insecurity in urban areas (Battersby, 2012). The focus remains largely on issues of availability and therefore finds solutions in increased food production through urban agriculture, whereas the challenge of urban food insecurity is primarily the one of access.

There has been a growing interest among policymakers and planners on the role of urban agriculture in addressing urban food insecurity, improving nutrition and increasing dietary diversity. However, according to Zezza and Tasciotti (2010), the evidence base to support the assumption of the growing interest among policymakers and planners on the role of urban agriculture in addressing urban food insecurity central role is weak. Warren et al. (2015) argue that this is because of the poor quality of study designs. According to Frayne, McCordic and Shilomboleni (2014), there are research studies which are specifically for African context and these studies revealed that the prevalence of urban agriculture varies greatly between cities as a result of their distinctive local histories and geographies and this is why it was difficult to generalise about the potential of urban agriculture to address food insecurity.

The vast majority of African urban residents obtain most of their food from various types of retail outlets (Crush and Frayne, 2011). According to Kennedy (2003), there are differences in the components of food security between urban and rural areas. The availability of food in urban areas comes from production in rural, and suburban areas and import (Kennedy, 2003). Complex distribution chains involving wholesalers, secondary buyers, distributors, and vendors define the systems of the urban food supply. On the one hand, these complex networks create jobs for residents of the city, yet, the longer the value chain means that the prices will be higher. Therefore, the urban poor households are vulnerable to changes in prices because their earnings and cash reserves are limited.

Urban access to food is divided into access and choice of food as well as access and food pattern (Mutiah and Istiqomah, 2017). In the urban area, the choice of food in the household is determined mostly by affordability and not necessarily accessibility. Due to the fast-paced urban lifestyle, many urban consumers now rely on fast food. Street food plays an important role in food access strategies of the urban poor (Mutiah and Istiqomah, 2017). The cost of traditional staple food is often higher in urban areas than the cost of processed food. People in urban areas consume more processed and prepared foods that in general contain more fat, sugar, salt, preservatives, and have less fibre and micronutrient content. This is because processed food is affordable, available and quick to prepare.

The use of urban food can be measured by looking at the individual's health status. Food security conditions in urban environments are often the subject of attention, because urban street food is often prepared in unhygienic conditions, and can cause disease outbreaks in food. As there are no farming activities in urban areas, people in the informal part of urban areas suffer from poverty and food insecurity since they find it difficult to access the larger formal markets and thus the larger formal supermarkets tend to locate closer to middle-class areas and are often only accessible by car, but are frequently able to sell cheaper than informal traders since they can access in bulk and have control over supply chains (Widayaningsih et al., 2016). Formal and informal retailers also link in a variety of ways and consequently the way the systems pattern spatially in any city, as well as the extent to which informal traders are being undermined by supermarkets, depends very much on context (Crush and Frayne, 2011).

According to the study by Mutiah and Istiqomah (2017) on the determinants of household food security in urban areas, education of household head and household income is positively associated with household food 
security. The positive relationship between the educational level and food security means that the higher the educational level, the higher the chance of household to be food secure. The positive relationship between household income and food security means that the higher the income, the higher the chance of household food security status. The higher the household income, the more likely the household is able to buy food with bigger quantity and better quality.

Food supply is a determinant of availability of food in urban areas. Food supply systems include a complex distribution chain which involves wholesalers, intermediaries, distributors and street vendors. Such a distribution chain has the potential of increasing the price of food which has a negative consequence due to the vulnerability of the urban poor to price increases (Van der Merwe, 2011). Access to food goes hand-in-hand with income availability and the urban poor often pays more for food since they are forced to buy small quantities of food due to limited income (Van der Merwe, 2011).

Food prices are a stressing factor to which the urban poor are extremely vulnerable. According to Ruel and Garrett (2004), food prices depend on five factors which are; the efficiency of the food marketing systems in urban areas; the buying patterns of the household (this refers to whether the family buys their food in bulk or in small quantities as well as where they purchase their food); the ability of the household to produce some of the food it needs through systems of urban agriculture; the household's access to public transfers such as food aid programs or subsidies; and macroeconomic policies of governments, including food policies. As indicated by Van der Merwe (2011), urban agriculture is viewed as one of the policy options to strengthen the asset base of the urban poor in South Africa.

The relationship between household asset and food security is important but is rarely acknowledged. Lacking assets such as refrigerators or some form of storage influences the volume and type of food to purchase. Shack dwellers in urban areas are more likely affected because of the lack of electricity. Similar results were found by Battersby (2012) and in addition, the most affected households are the ones located far from the formal markets hence this limits them from accessing cheaper food.

Again, using a logistic regression model to determine the determinants of food security, De Cock et al. (2013) found that human capital, household income and household geographical location seem to be the most important determinants of food security. The analysis further outlines that household size, household income and getting remittances are part and parcel of factors contributing to household food security in rural areas. Smaller households with older and educated people are more likely to be food secure than most households with lots of children and low level of education. The odds of food insecurity are with households receiving little income or depending on a single income. Again, when a family survive on remittance as its main source of income, its probability of being food secure is higher.

\section{Conclusion}

This review paper was aimed at finding out if the correlates of food security status in rural and urban South Africa are the same considering the changing socioeconomic, political and cultural settings in the country. After South Africa gained its freedom from the apartheid regime, the focus shifted and policies were implemented to advance and make sure they tackle the issues of food insecurity. From 1994 to date, food security problems are yet to be addressed holistically but instead, the food security situation seems to be getting worse by the day as found in most of the countries in sub-Sahara Africa. The scenario depicted above indicated that some of the figures or statistics provided by Statistics South Africa portrayed a declining trend in the number of foodinsecure households nationally. The appalling revelation is that the same cannot be said at the household and individual levels especially in the rural areas of virtually all the provinces in the country. For example, provinces dominated by rural areas like Limpopo and Eastern Cape showed a decrease in the percentages of food-secure households. The concluding statement from the determinants of household food security is that some of the variables or rather the determinants correlate and others do not correlate in both rural and urban areas.

From the findings, household income and educational status among others seem to be the most predominant factor influencing household food security. This is because income earners are better off and having good education increases the chances of a person harnessing opportunities and the likelihood of getting a better-paying job is enhanced.

Based on the foregoing, the following policy prescriptions are suggested;

- Enhancement of capacity building among rural dwellers as this will create better and decent platforms to access job opportunities for people in rural areas.

- Agricultural education should also be prioritised and made fashionable in rural communities so that the farmers with more farming experience can educate 
and empower other farmers.

- Households should be encouraged to explore other non-agricultural income-generating activities as this will help in augmenting income available to buy food.

\section{Conflict of interest}

The authors declare no conflict of interest.

\section{References}

Aliber, M. (2009). Exploring Statistics South Africa's National Household Surveys as Sources of Information about Food Security and Subsistence Agriculture. Unpublished Report, Centre for Poverty Employment and Growth. Pretoria, South Africa: Human Sciences Research Council. https:// doi.org/10.1080/03031853.2009.9523833

Battersby, J. (2012). Beyond the Food Desert: Finding Ways to Speak about Urban Food Security in South Africa. Geografiska Annaler: Series B, Human Geography, 94(2), 141-159. https://doi.org/10.1111/ j.1468-0467.2012.00401.x

Bwalya, M. (2013). Comprehensive Africa Agriculture Development Programme (CAADP) to Reduce Food Security Emergencies in Africa. Johannesburg, South Africa: NEPAD Planning and Coordinating Agency.

Chakona, G. and Shackleton, C.M. (2019). Food insecurity in South Africa: To what extent can social grants and consumption of wild foods eradicate hunger? World Development, 13, 87-94. https:// doi.org/10.1016/j.wdp.2019.02.001

Crush, J. and Frayne, B. (2011). Supermarket Expansion and the Urban Food Economy in Southern African cities: Implications for Urban Food Security. Journal of Southern African Studies, 37(4), 781-807. https:// doi.org/10.1080/03057070.2011.617532

DAFF (2011). Department of Agriculture, Forestry and Fisheries, Directorate Economic Services Production Economics unit. Retrieved on 17 May 2020 from: http://www.nda.agric.za/docs/genreports/ foodsecurity.pdf

De Cock, N., D’Haese, M., Vink, N., van Rooyen, C.J., Staelens, L., Schönfeldt, H.C. and Dhaese, L. (2013). Food security in rural Limpopo province, South Africa. Food Security, 5(2), 269-282. https:// doi.org/10.1007/s12571-013-0247-y

Demetre, L., Yul, D. and Zandile, M. (2009). The Assessment of Food Insecurity in South Africa. Retrieved from Human Sciences Research Council website: www.hsrc.ac.za. du Toit, D.C. (2011). Food Security: Discussion Notes on Food Security. Pretoria, South Africa: Directorate Economic Services and Production Economics Unit, DAFF.

FAO, ECA and AUC (2020). Africa Regional Overview of Food Security and Nutrition 2019. Accra, Ghana: FAO. https:/doi.org/10.4060/CA7343EN

Food and Agriculture Organization (FAO). (2004). The State of Food Insecurity in the World. Addressing food insecurity in protracted crises, p. 43. Rome, Italy: Food and Agricultural Organization of the United Nations

Food and Agriculture Organization (FAO). (2008). Deriving Food Security Information from National Household Budget Surveys: Experiences, Achievements, Challenges, p. 186. Rome, Italy: Food and Agricultural Organization of the United Nations.

Frayne, B., McCordic, C. and Shilomboleni, H. (2014). Growing Out of Poverty: Does Urban Agriculture Contribute to Food Security in South African Cities? Urban Forum, 25, 177-189. https://doi.org/10.1007/ s12132-014-9219-3

Grobler, W.C.J. (2015). The Determinants of Urban Food Security: Insights from A Low Income Neighbourhood in South Africa. Proceedings of the $15^{\text {th }}$ International Academic Conferences, $p$. 1003643. Rome: International Institute of Social and Economic Sciences.

Hart, T. (2009). The Status of Household Food Security Targets in South Africa. Agricultural Economics Research, Policy and Practice in Southern Africa, 48 (4), 362-383. https:// doi.org/10.1080/03031853.2009.9523831

Krishnaraj, M. (2005). Food Security: How and for Whom? Economic and Political Weekly, 40(25), 2508-2512. Retrieved from http://www.jstor.org/ stable/4416779.

Labadarios, D., Mchiza, Z.J.R., Steyn, N.P., Gericke, G., Maunder, E.M.W., Davids, Y.D. and Parker, W.A. (2011). Food Security in South Africa: A Review of National Surveys. Bulletin of the World Health Organization, 89, 891-899. https://doi.org/10.2471/ BLT.11.089243

Landman, A.P. (2004). Nutrition-sensitive Agriculture A South African Perspective. Food Security, 5(6), 857-871. https://doi.org/10.1007/s12571-013-0309-1

Machethe, C.L. (2004). Agriculture and Poverty in South Africa: Can Agriculture Reduce Poverty? Paper Presented at the Conference on Overcoming Underdevelopment, October 28-29, 2004. Pretoria, South Africa. 
Millennium Development Goals - MDGs (2015) Country Report 2015, Statistics South Africa, p. 1157. Pretoria, South Africa: Statistics South Africa.

Mutiah, S.A. and Istiqomah, I. (2017). Determinants of Household Food Security in Urban Areas. Journal Ekonomi dan Kebijakan, 10(1), 103-120. https:// doi.org/10.15294/jejak.v10i1.9130

Ndobo, F.P. (2013). Determining the Food Security Status of Households in the South African Township. South Africa: North West University, BSc. Thesis.

Oluwatayo, I.B. (2019). Towards Assuring Food Security in South Africa: Smallholder Farmers as Drivers. AIMS Agriculture and Food, 4(2), 485-500. https://doi.org/10.3934/agrfood.2019.2.485

Pinstrup-Andersen, P. (2009). Food Security: Definition and Measurement. Food Security, 1(1), 5-7. https:// doi.org/10.1007/s12571-008-0002-y

Ramaila, M., Mahlangu, S. and du Toit, D. (2011). Agricultural Productivity in South Africa: Literature Review. South Africa: Economics Services Production Economics Unit, DAFF, South Africa,

Ruel, M.T. and Garret, J.L. (2004). Features of Urban Food and Nutrition Security and Considerations for Successful Urban Programming. Journal of Agricultural and Development Economics, 1(2), 242 -271 .

Sen, A.K. (1981). Ingredients of Famine Analysis: Availability and Entitlements. Quarterly Journal of Economics, 96(3), 433-464. https:// doi.org/10.2307/1882681

South African National Health and Nutrition Examination Survey - SANHANES. (2013). SANHANES -1, p. 423. Cape Town, South Africa, HSRC Press.

Statistics South Africa (2017). The General Household Survey. Statistical Release P0318. Pretoria: Statistics South Africa.

Statistics South Africa. (2019). The General Household Survey. Towards Measuring the Extent of Food Security in South Africa: An Examination of Hunger and Food Inadequacy, Statistical Release P0318. Pretoria: Statistics South Africa.

United Nations (2012). Economic and Social Council [Internet]. Economic and Social Council briefed by top UN officials on work of Global Food Crisis Task Force: outcome of November World Summit on Food Security. New York: Retrieved on 26 May 2019 from United Nations website: http:// www.un.org/News/Press/docs/2009/ ecosoc6401.doc.htm

Van der Merwe, C. (2011). Key Challenges for Ensuring
Food Security in South Africa's Inner Cities. Brief No. 36. South Africa: Africa Institute of South Africa (AISA). Retrieved from: http:// www.ai.org.za/wp-content/uploads/ downloads/2011/11/No-36.-Key-Challenges-forEnsuring-Food-Security-in-South-Africas-InnerCities.pdf

van Zyl J. and Kirsten J. (1992). Food Security in South Africa. Department of Agricultural Economics, Extension, and Rural Development, University of Pretoria, 31(4),170-184. https:// doi.org/10.1080/03031853.1992.9524684

Voster, H.H. (2010). The Link between Poverty and Malnutrition: A South African Perspective. Health SA Gesondheid 15(1), 435-441. https:// doi.org/10.4102/hsag.v15i1.435

Warren, E., Hawkesworth, S. and Knai, C. (2015). Investigating the Association between Urban Agriculture and Food Security, Dietary Diversity, and Nutritional Status: A Systematic Literature Review. Food Policy, 53, 54-66. https:// doi.org/10.1016/j.foodpol.2015.03.004

Widayaningsih, Neni and Barokatuminalloh. (2011). Analisis ketahanan pangan rumah tangga di desa miskin di Kecamatan Sumbang Kabupaten Banyumas. Jurnal Pembangunan Ekonomi Wilayah, 6(1), 51-61.

Widayaningsih, Neni and Barokatuminalloh. (2016). Strategy of Increasing Food Security Based on Macro - and Micro Aspects. Journal Economy dan Kebijakan, 9(1), 111-128.

Zezza, A. and Tasciotti, L. (2010). Urban Agriculture, Poverty and Food Security: Empirical Evidence from a Sample of Developing Countries. Food Policy, 35 (4), 265-73. https://doi.org/10.1016/ j.foodpol.2010.04.007 